\title{
Effect of Cadmium and Zinc on Growing Barley
}

\author{
N. Kherbani*, N. Abdi, H. Lounici \\ Research Unit of Engineering and Environment, National Polytechnic School of El Harrach, Algiers, Algeria \\ Email: ${ }^{*}$ kherbani@yahoo.fr
}

Received 14 November 2014; accepted 13 February 2015; published 25 February 2015

Copyright (C) 2015 by authors and Scientific Research Publishing Inc.

This work is licensed under the Creative Commons Attribution International License (CC BY). http://creativecommons.org/licenses/by/4.0/

(C) (i) Open Access

\section{Abstract}

The accumulation of metals, in particular of metals known as heavy in the plants poses problem. However, so with the state of traces, these metals are essential to the life, they can with stronger concentrations appear toxic. So to limit the risks, we have to study the effects of these pollutants on the living organisms. Among the techniques of phytorehabilitation, we find the phytoextraction. So, we are interested in the phytoextraction in the barley (Hordium vulgare) of a soil contaminated artificially by zinc and cadmium and the influence of these metals presence on the barley growth. The results show that the barley is tolerant in the zinc and the cadmium; it presents no sign of stress after 4 weeks of culture in soil contaminated by these metals. The accumulated zinc arrests at the level of roots and it is not transferred towards the air parts. On the other hand, the barley accumulates more cadmium compared to zinc.

\section{Keywords}

Cadmium, Zinc, Plants, Barley, Phytoextraction

\section{Introduction}

Most sites contaminated with heavy metals, often have a diverse flora tolerant apparently well high levels of metals. The phytorehabilitation is based on the use of plants for the remediation of contaminated sites. It is defined as the use of plants to remove or render less mobile and less toxic environmental contaminants. These techniques are not very aggressive to the environment and relatively inexpensive. They can be applied to organic or inorganic pollutants.

Among these techniques, the phytoextraction relates to mainly the metals absorption of the ground with the plants. The ideal plant for the phytoextraction must be able to accumulate and tolerate strong contents of metals:

\footnotetext{
*Corresponding author.
} 
they are plants known as accumulator or hyper accumulator. The phytoextraction term relates to mainly the absorption of the ground metals with the plants. The plants can accumulate metals, such as: $\mathrm{Fe}, \mathrm{Mn}, \mathrm{Zn}, \mathrm{Cu}, \mathrm{Mg}$, Mo, necessary to their good development, but are also able to accumulate metals, such as: $\mathrm{Cd}, \mathrm{Cr}, \mathrm{Pb}, \mathrm{Co}, \mathrm{Ag}$, Hg. The tolerance and this bioaccumulation are made possible by an adaptation of the plant, with the introduction of new cellular level of physiological capacities [1] [2]. The best plant for the phytoextraction must be able to accumulate and tolerate strong contents of metals in its parts ready for harvesting, while having a rapid growth and a strong biomass [3]. Certain plants are naturally able to accumulate strong contents of metals, they are accumulating plants, the accumulated contents are higher than those present in the ground. Some are known as hyper accumulator, if they are able to accumulate more than $10,000 \mathrm{mg} \cdot \mathrm{kg}^{-1}$ of $\mathrm{Mn}$ or $\mathrm{Zn}$, more than 1000 $\mathrm{mg} \cdot \mathrm{kg}^{-1}$ of $\mathrm{Cu}, \mathrm{Co}, \mathrm{Ni}, \mathrm{Pb}, \mathrm{Cr}$, or more than $50 \mathrm{mg} \cdot \mathrm{kg}^{-1}$ of Cd in their leaves. Unfortunately, although there exists more than 400 listed plant species metal hyper accumulator heavy, they are generally with slow growth and a weak production of biomass; moreover, most of them are found exclusively in tropical regions, and more than 80\% are hyper accumulator as the nickel [4] [5]. This strategy of phytoextraction depends on the plant used, that is to say, its ability to extraction, accumulation, translocation (transfer of the pollutant of the roots towards the leaves) as well as to resist strong contents of metals. Most known growth on soil contains strong contents of metals. The present study aims to investigate the effects of the presence of heavy metals (cadmium and zinc) on the growth of barley cultivated in a ground contaminated artificially by these two metals at various concentrations, the growth parameters which we followed are the biomass of the plant and the length of roots and leaves. We also studied the capacities of phytoextraction by barley (Hordium vulgare) that is to say it's the capacity of extraction, accumulation and translocution, we determined the bioaccumulation factor and the translocution factor.

\section{Material and Methods}

\subsection{Sampling}

The soil chosen as model of study is a soil which comes from the National Institute of Agronomy of El Harrach (Algiers). The samples of ground were taken in a $5-10 \mathrm{~cm}$ depth. The site of taking away is in a zone distant from any roads and all industrial activities having an agricultural activity. The sample of the studied ground was treated according to the standard ISO 11464 . It is dried with the free air $\left(20^{\circ} \mathrm{C} \pm 2^{\circ} \mathrm{C}\right)$ is crushed and filtered on a sieve of mesh of $2 \mathrm{~mm}$, then preserved in a dry place.

\subsection{Physico-Chemical Analyses of the Soil}

\subsection{1. $\mathrm{pH}_{\text {water }}$ and $\mathrm{pH}_{\mathrm{KCl}}$}

The measures of $\mathrm{pH}_{\text {water }}$ and $\mathrm{pH}_{\mathrm{KCl}}$ are taken according to the standard ISO 10390, $10 \mathrm{~g}$ of soil are put in suspension in $25 \mathrm{~mL}$ of distilled water (or potassium chloride, $\mathrm{KCl}$ in $1 \mathrm{~mol} \cdot \mathrm{L}^{-1}$ ), agitated during 1 hour then left with the rest during 2 hours. The $\mathrm{pH}$ is then measured using a $\mathrm{pH}$-meter. The $\mathrm{pH}_{\text {water }}$ measures the real acidity and takes into account the ions $\mathrm{H}_{3} \mathrm{O}^{+}$free in the solution of the ground. The $\mathrm{pH}_{\mathrm{KCl}}$ measures the potential acidity which takes into account the ions $\mathrm{H}_{3} \mathrm{O}^{+}$free in the solution of the soil and those moved by the $\mathrm{KCl}$. The granulometry was determined by following the NF standard X 31 - 107 (French National Organization for Standardization 2004) and at the level of the soil analysis laboratory of the INRA.

It represents the fraction of water stored in micropores, capacity of retention. In water is measured according to the method by pressure the principle of which bases on the determination of the water quantity of a sample of ground retained under a strength of retention not exceeding $1000 \mathrm{~g} \cdot \mathrm{cm}^{-2}[6]$.

\subsubsection{Cation Exchange Capacity (CEC)}

The cation exchange capacity CEC represents the total quantity of exchangeable cations that the soil can adsorb. The CEC was determined by the method cobaltihexamine chloride $\left(\mathrm{Co}\left(\mathrm{NH}_{3}\right) 6 \mathrm{Cl}_{3}\right)$ according to standard $\mathrm{NF} \mathrm{X}$ 31 - 130 (AFNOR, 2004). The principle of this method is that the ions cobaltihexamine $\left(\mathrm{Co}\left(\mathrm{NH}_{3}\right)_{6}^{3+}\right)$ adsorb to the surface and thereby move the cations selected from the soil. For this, $5 \mathrm{~g}$ of soil was suspended in $25 \mathrm{ml}$ of a solution of $\mathrm{Co}\left(\mathrm{NH}_{3}\right) 6 \mathrm{Cl}_{3}$ at $0.016 \mathrm{~mol} \cdot \mathrm{L}^{-1}$, stirred for $3 \mathrm{~h}$, centrifuged $(15 \mathrm{~min}$ at $3000 \mathrm{~g})$ and filtered $(0.45 \mu \mathrm{m}$, cellulose nitrate filter-Sartorius). Ions $\mathrm{Co}\left(\mathrm{NH}_{3}\right)_{6}^{3+}$ remained in excess in the solution is then determined colorimetrically at $470 \mathrm{~nm}$ using a UV-Visible spectrophotometer. CEC is expressed in meq/100g soil. The assay 
of $\mathrm{K}^{+}$cations, and $\mathrm{Na}^{+}$is made by flame spectrophotometry.

\subsubsection{Organic Carbon Content}

The content in organic carbon was determined according to the standard ISO 14235. It is about an oxidation of the organic carbon of the soil by the bichromate of potassium $\left(\mathrm{K}_{2} \mathrm{Cr}_{2} \mathrm{O}_{7}\right)$ in excess, in acid medium $\left(\mathrm{H}_{2} \mathrm{SO}_{4}\right)$, and hot. The chromium VI is reduced by the organic carbon to chromium III. The remaining Cr VI is then measured. For that purpose, $150 \mathrm{mg}$ of soil are mixed in $5 \mathrm{~mL}$ of a solution of potassium bichromate to $0.27 \mathrm{~mol} \cdot \mathrm{L}^{-1}$ and in $7.5 \mathrm{~mL}$ of concentrated sulphuric acid. After centrifugation and filtration $(0.45 \mu \mathrm{m})$, the $\mathrm{Cr}$ VI is measured in $580 \mathrm{~nm}$ by means of an UV-VISIBLE spectrophotometer. The dosage remits in a curve of calibration established from glucose, which undergoes the same protocol as the ground.

\subsubsection{Evaluation of the Total Limestone $\mathrm{CaCO}_{3}$}

Volumetric determination of the carbon dioxide $\left(\mathrm{CO}_{2}\right)$ released under the effect of an acid very at room temperature (of the laboratory) by the sample of ground prepared for essay (French National Organization for Standardization, on 1987).

\subsubsection{Total Nitrogen Content}

The content in total nitrogen is determined by the method Kjeldahl, this standard has for principle to mineralize the organic nitrogen by the sulphuric acid in the presence of an activator of mineralization, distillation of the ammoniacal formed nitrogen and titration in a solution of boric acid (French National Organization for Standardization, on 1987).

\subsection{Analysis of Metals}

\subsubsection{Equipment}

The quantification of metals in solution is performed by atomic absorption spectroscopy (AAS). In AAS, the analyses are realized using a spectrophotometer (correction of background noise by deuterium lamp). The produced flame is a flame air/acetylene. In the case of $\mathrm{Cr}$, it is reducing and in other cases, it is oxidizing.

\subsubsection{Determination of Total Content}

The quantification of the metal content "total" requires dissolution of the soil. So we chose the protocol using

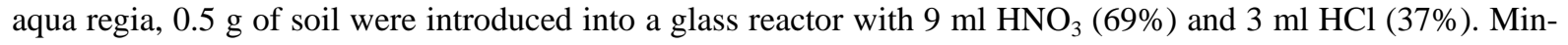
eralization is realized using a digester. The digests are then brought to a final volume of $50 \mathrm{ml}$ with distilled water. The metals were analyzed by AAS.

\subsection{Fertilization}

We work with a soil having been already of use to an agricultural activity, this soil is poor in nitrogen, phosphor and potassium; we thus proceeded to fertilization. The quantities are estimated on the basis of the recommendations of T I.B.C (Technical Institute of the Big Cultures), N/P/K: 70/50/50 unity by hectare for the Hordium vulgare. The used products are: the urea as the source of nitrogen; $\mathrm{KH}_{2} \mathrm{PO}_{4}$ as source of phosphor, $\mathrm{K}_{2} \mathrm{SO}_{4}$ as source of potassium. Products are dissolved in some demineralized water.

\subsection{Artificial Contamination}

The ground is filled in 30 pots with 15 pots are contaminated with zinc. For that, solutions were prepared from the zinc sulfate and were added to the soil so that it is substantially in the soil after addition: 500, 1000, 2000, 3000 and $4000 \mathrm{mg}$ of zinc per kg of soil (3 pots for each concentration). The contamination was realized by applying the solution of zinc corresponding to $90 \%$ of water saturation on the surface, and it is maintained for $24 \mathrm{~h}$ at room temperature until complete absorption of the solution.

The remaining 12 pots are contaminated by cadmium. For this, solutions were prepared from the cadmium sulfate were added to the soil so that it is added in the soil after 25, 50, 100 and $200 \mathrm{mg}$ of cadmium per $\mathrm{kg}$ of soil (three pots for each concentration) by following the same procedure applied to the soil contaminated with zinc. The remaining three pots are not contaminated and therefore serve as a witness. 


\subsection{Culture Protocol}

The Hordeum vulgare (barley) was planted on October 19th, 2009 and cultivated on November 19th, 2009 under natural light in an ambient temperature between $14^{\circ} \mathrm{C}-23^{\circ} \mathrm{C}$, the seeds used come from TIBC. During this phase of growth, the plants are watered to $90 \%$ of their capacity in order to maintain retention of the nutrients, and especially to maintain the metals in the soil and prevent leakage. The volume of water added depends on the water retention capacity of the soil and water requirements of the plant. During the culture, all the plants are sprayed with water. The amount of water to add is determined after all of the weighing pot-soil-plant.

Was stopped after one month of culture, we proceed to the separation of the root portion of the aerial part (leaves) by cutting the plant at the root bulb separate leaves. The plant material was dried at $40^{\circ} \mathrm{C}$ for 72 hours and then ground in a mortar (porcelain). The digestion is carried out to determine the metal content in the plant. The metal content in the different parts of the plant (root, leaves) was determined after acid digestion. One introduced into the glass reactors $1 \mathrm{~g}$ of dry plant material and $10 \mathrm{ml}$ of $69 \% \mathrm{HNO}_{3}$. The dissolution is carried out in accordance with a temperature program: $200^{\circ} \mathrm{C}$ for $30 \mathrm{~min}$. The digests are then brought to a final volume of $50 \mathrm{ml}$ with distilled water. The metals were analyzed by AAS.

\subsection{Determination of Growth Parameters}

After the culture of the barley, we proceeded to the determination of the growth parameters namely: the length of the leaf, the length of the root, the dry weight biomass (roots and leaves). The dry weight was determined after drying of biomass for 72 hours at $40^{\circ} \mathrm{C}$.

\subsection{Determination of the Bioaccumulation Factor}

The presence of metals in the various parts of the plant indicates that there is accumulation but also translocation towards the air parts (transport of these elements of the roots towards the air parts). Accumulation and the translocation can be evaluated by two parameters: the bioaccumulation factor and the translocation factor.

The bioaccumulation factor is described as: $\mathrm{BF}=\frac{\mathrm{C}_{\mathrm{HMP}}}{\mathrm{C}_{\mathrm{HMS}}}$.

$\mathrm{C}_{\mathrm{HMP}}$ : Concentration of heavy metals in the plant.

$\mathrm{C}_{\text {Hмs: }}$ : Concentration of heavy metals in the soil.

\subsection{Determination of the Translocation Factor}

The presence of metals in different parts of the plant indicating that there is accumulation but also translocation to the aerial parts, that is to say, the transport of these roots to shoots. The accumulation and translocation can be measured by two parameters: the factor translocation and accumulation factor.

The translocation factor (FT) is used to assess the capacity of phytoextraction plants, more particularly, it indicates the ability of the plant to transfer the metal from the root to the leaves, is calculated as follows:

$$
\mathrm{FT}=\frac{\mathrm{T}_{\mathrm{AP}}}{\mathrm{T}_{\mathrm{RP}}} .
$$

$\mathrm{T}_{\mathrm{AP}}$ : metal content in the aerial parts $\left(\mathrm{mg} \cdot \mathrm{kg}^{-1}\right)$.

$\mathrm{T}_{\mathrm{RP}}$ : metal content in the root portions $\left(\mathrm{mg} \cdot \mathrm{kg}^{-1}\right)$.

\section{Results}

\subsection{Soil Characterization}

\section{Physicochemical Properties}

The physicochemical characterization of the soil was realized by following the standardized protocols. All the results are presented at Table 1 . The results of granulometry highlight that the sample of soil mainly consists of silt and clay. If we refer to a diagram of texture [1], it is classified limonoclayey. It presents a little basic $\mathrm{pH}$, a low content in organic carbon. Table 1 describes the physicochemical properties of the ground sample. 
Table 1. Physicochemical properties of the soil sample.

\begin{tabular}{|c|c|c|}
\hline Parameters & Units & Soil \\
\hline Clay $(<2 \mu \mathrm{m})$ & $\mathrm{g} \cdot \mathrm{kg}^{-1}$ & 33.27 \\
\hline Fine silt $(2 / 20 \mu \mathrm{m})$ & & 25.31 \\
\hline Coarse silt $(20 / 50 \mu \mathrm{m})$ & & 18.62 \\
\hline Fine sand $(50 / 200 \mu \mathrm{m})$ & & 15.56 \\
\hline Coarse sand $(200 / 2000 \mu \mathrm{m})$ & & 7.79 \\
\hline $\mathrm{pH}_{\text {water }}$ & & 8.12 \\
\hline $\mathrm{pH}_{\mathrm{KCl}}$ & & 7.8 \\
\hline CEC & meq/100g & 20.55 \\
\hline Organic carbon (CO) & & 1.25 \\
\hline $\mathrm{N}$ total & & 0.13 \\
\hline $\mathrm{Ca}^{2+}$ & & 15.6 \\
\hline $\mathrm{Mg}^{2+}$ & & 2.35 \\
\hline $\mathrm{Na}^{+}$ & & 0.18 \\
\hline $\mathrm{K}^{+}$ & & 1.2 \\
\hline $\mathrm{CaCO}_{3}$ & & 5.25 \\
\hline $\mathrm{P}_{2} \mathrm{O}_{5}$ & & 21.06 \\
\hline $\mathrm{Zn}$ & $\mathrm{mg} \cdot \mathrm{kg}^{-1}$ & 72 \\
\hline $\mathrm{Cd}$ & & 0 \\
\hline
\end{tabular}

\subsection{Effects of Cadmium on the Growth of the Barley}

Following a contamination by cadmium, Table 2 indicates the total biomass as well as the length of the root and the leaves.

The evolution length of the roots and leaves according to the concentration of cadmium are represented by Figure 1 and Figure 2.

The evolution of the dry weight of the roots and the leaves is represented by Figure 3 . The total follow-up of the biomass (roots + sheets) is given by Figure 4 .

\subsection{Effects of Zinc on the Growth of the Barley}

Following a contamination by zinc, Table 3 indicates the total biomass as well as the length of the root and the leaves.

The evolution length of the roots and leaves according to the concentration of zinc are represented by Figure 5 and Figure 6.

The evolution of the dry weight of the roots and the leaves is represented by Figure 7. The total follow-up of the biomass (roots + sheets) is given by Figure 8 .

\subsection{Follow-Up of the Zinc Content and Cadmium in the Barley}

\subsubsection{Content and Accumulation of Cadmium in Barley}

After the digestion of the roots and leaves of the barley while following the protocol quoted previously, we performed the analysis of cadmium in roots and leaves of the harvested plant, the results are represented in Figure 9. We have also represented the cadmium cumulated by all the roots and leaves in Figure 10. These results enabled us to determine the bioaccumulation factor and factors translocution for each cadmium concentration in 
Table 2. Effect of cadmium on the contamination by the length and the dry weight of the roots and leaves of barley.

\begin{tabular}{cccccc}
\hline $\begin{array}{c}\text { Contamination } \\
\text { By Cd (mg/kg of soil) }\end{array}$ & $\begin{array}{c}\text { Length of the } \\
\text { roots }(\mathrm{cm})\end{array}$ & $\begin{array}{c}\text { Length of the } \\
\text { leaves }(\mathrm{cm})\end{array}$ & $\begin{array}{c}\text { Dry weight } \\
\text { of the roots }(\mathrm{g})\end{array}$ & $\begin{array}{c}\text { Dry weight } \\
\text { of the leaves }(\mathrm{g})\end{array}$ & Total biomass $(\mathrm{g})$ \\
\hline 0 (Control) & $20.95 \pm 1.30$ & $22.00 \pm 1.40$ & $0.1234 \pm 0.0021$ & $0.4641 \pm 0.0031$ & $0.5875 \pm 0.0026$ \\
25 & $18.50 \pm 1.20$ & $21.16 \pm 1.30$ & $0.1204 \pm 0.0035$ & $0.4488 \pm 0.0028$ & $0.5808 \pm 0.0032$ \\
50 & $18.24 \pm 1.50$ & $20.67 \pm 1.30$ & $0.1320 \pm 0.0028$ & $0.4245 \pm 0.0038$ & $0.5715 \pm 0.0033$ \\
100 & $17.45 \pm 1.20$ & $19.87 \pm 1.35$ & $0.1271 \pm 0.0017$ & $0.4443 \pm 0.0042$ & $0.5449 \pm 0.0034$ \\
200 & $16.03 \pm 1.30$ & $19.18 \pm 1.35$ & $0.1163 \pm 0.0019$ & $0.4191 \pm 0.0049$ & $0.5354 \pm 0.0034$ \\
\hline
\end{tabular}

Table 3. Effect of zinc on the contamination by the length and the dry weight of the roots and leaves of barley.

\begin{tabular}{cccccc}
\hline $\begin{array}{c}\text { Contamination } \\
\text { By Zn (mg/kg of soil) }\end{array}$ & $\begin{array}{c}\text { Length of the } \\
\text { roots }(\mathrm{cm})\end{array}$ & $\begin{array}{c}\text { Length of the } \\
\text { leaves }(\mathrm{cm})\end{array}$ & $\begin{array}{c}\text { Dry weight } \\
\text { of the roots }(\mathrm{g})\end{array}$ & $\begin{array}{c}\text { Dry weight } \\
\text { of the leaves }(\mathrm{g})\end{array}$ & $\begin{array}{c}\text { Total biomass } \\
(\mathrm{g})\end{array}$ \\
\hline 0 (Control) & $20.95 \pm 1.30$ & $22.00 \pm 1.40$ & $0.1444 \pm 0.0015$ & $0.5202 \pm 0.0047$ & $0.6646 \pm 0.0031$ \\
500 & $20.40 \pm 1.20$ & $20.83 \pm 1.30$ & $0.1293 \pm 0.0009$ & $0.5234 \pm 0.0038$ & $0.7164 \pm 0.0024$ \\
1000 & $19.98 \pm 1.30$ & $20.66 \pm 1.10$ & $0.1425 \pm 0.0012$ & $0.5497 \pm 0.0042$ & $0.6922 \pm 0.0027$ \\
2000 & $19.60 \pm 1.10$ & $19.77 \pm 0.90$ & $0.1618 \pm 0.0018$ & $0.6396 \pm 0.0034$ & $0.6679 \pm 0.0026$ \\
3000 & $19.48 \pm 0.90$ & $19.73 \pm 1.40$ & $0.1445 \pm 0.0026$ & $0.5546 \pm 0.0031$ & $0.6689 \pm 0.0029$ \\
4000 & $19.14 \pm 1.10$ & $19.65 \pm 1.20$ & $0.1295 \pm 0.0023$ & $0.4876 \pm 0.0051$ & $0.6171 \pm 0.0037$ \\
\hline
\end{tabular}

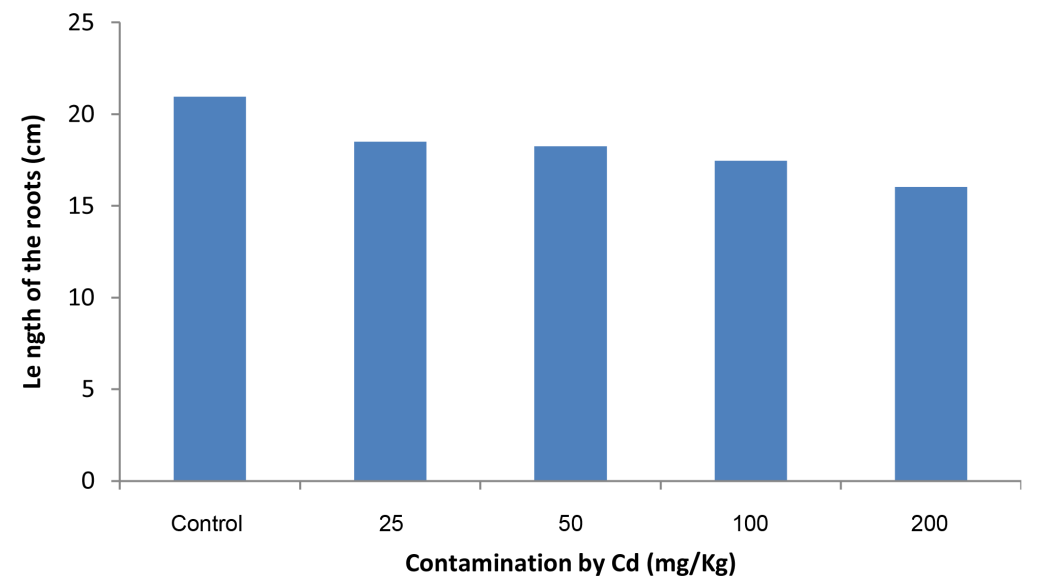

Figure 1. Evolution length of the roots according to the concentration of cadmium in the soil.

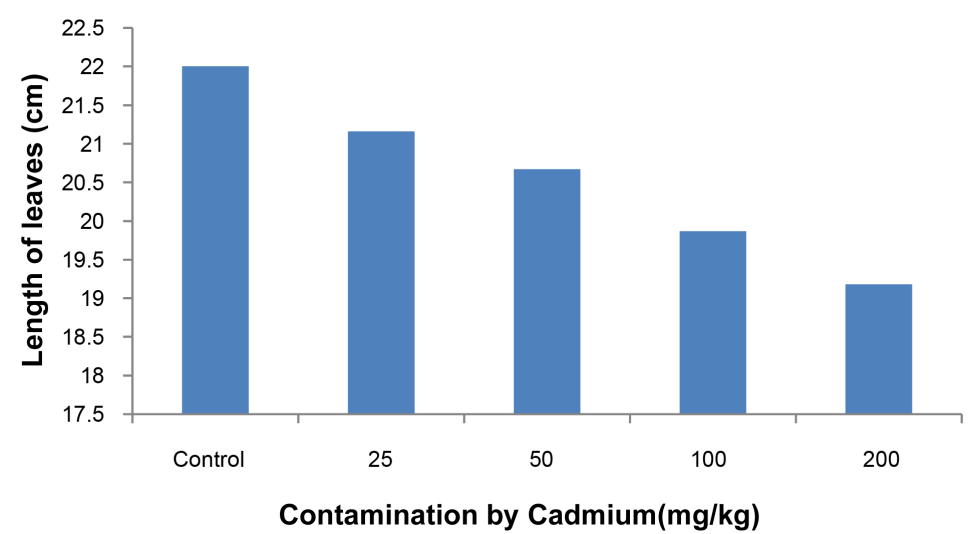

Figure 2. Evolution length of the leaves according to the concentration of cadmium in the soil. 


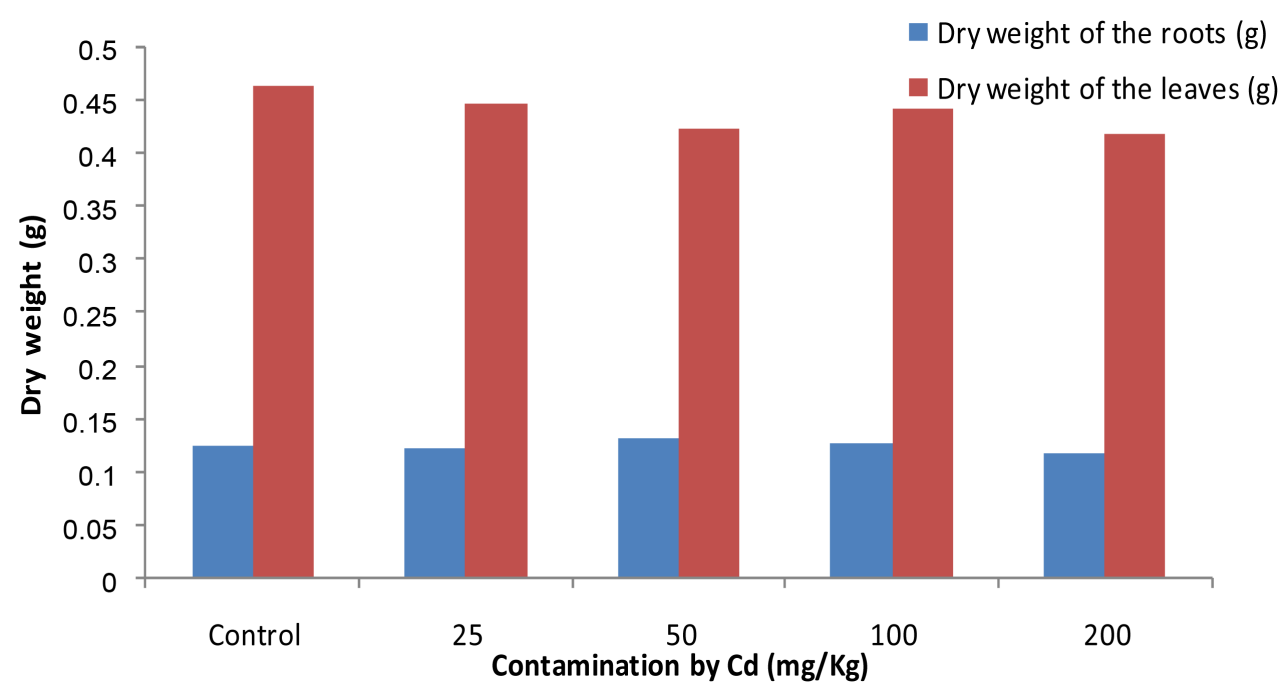

Figure 3. Dry weight of the roots and the leaves according to the contamination by cadmium.

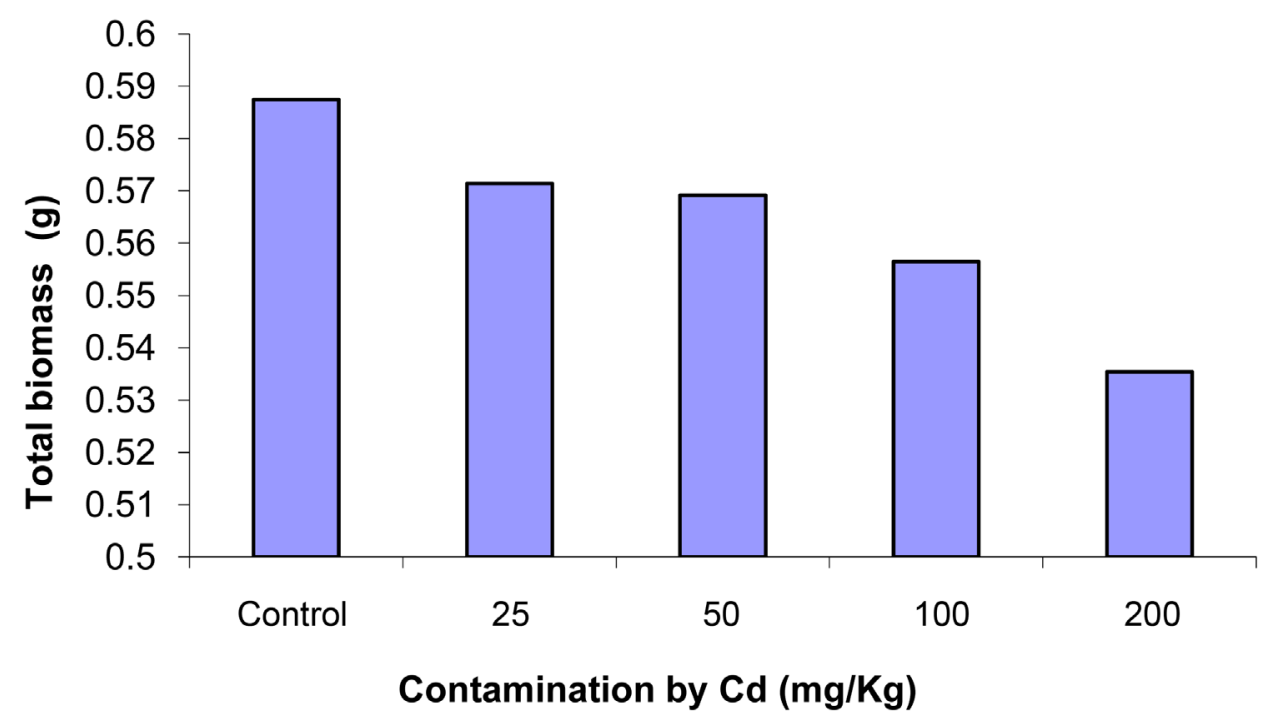

Figure 4. Evolution of the total biomass according to the contamination by cadmium.

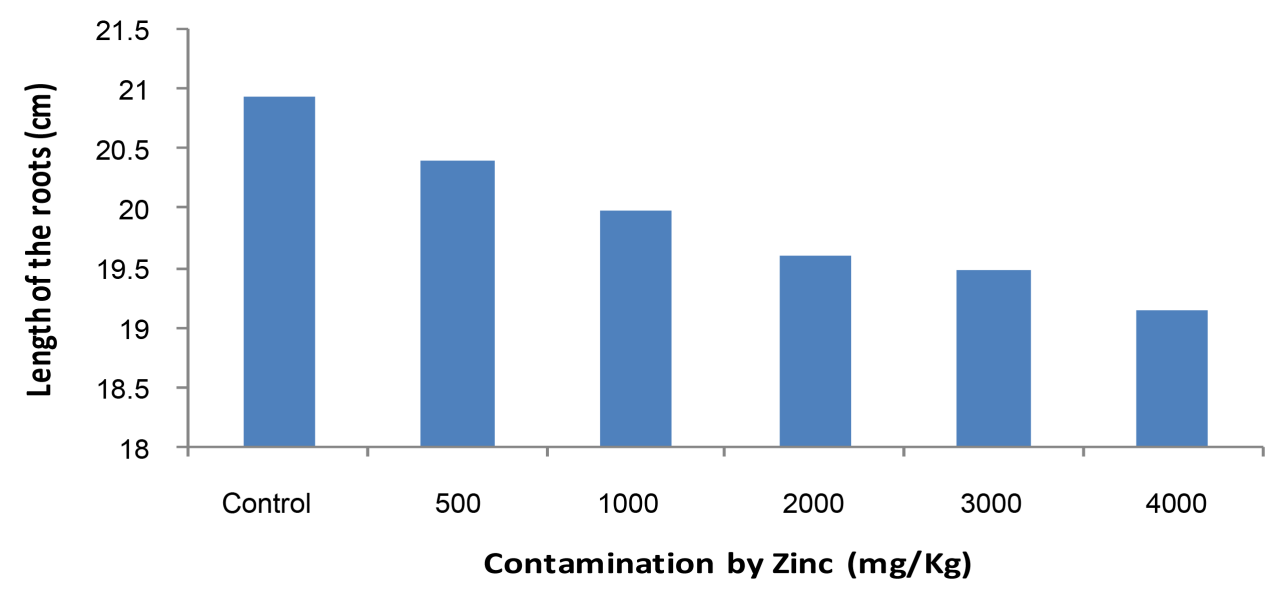

Figure 5. Evolution length of the roots according to the concentration of zinc in the soil. 


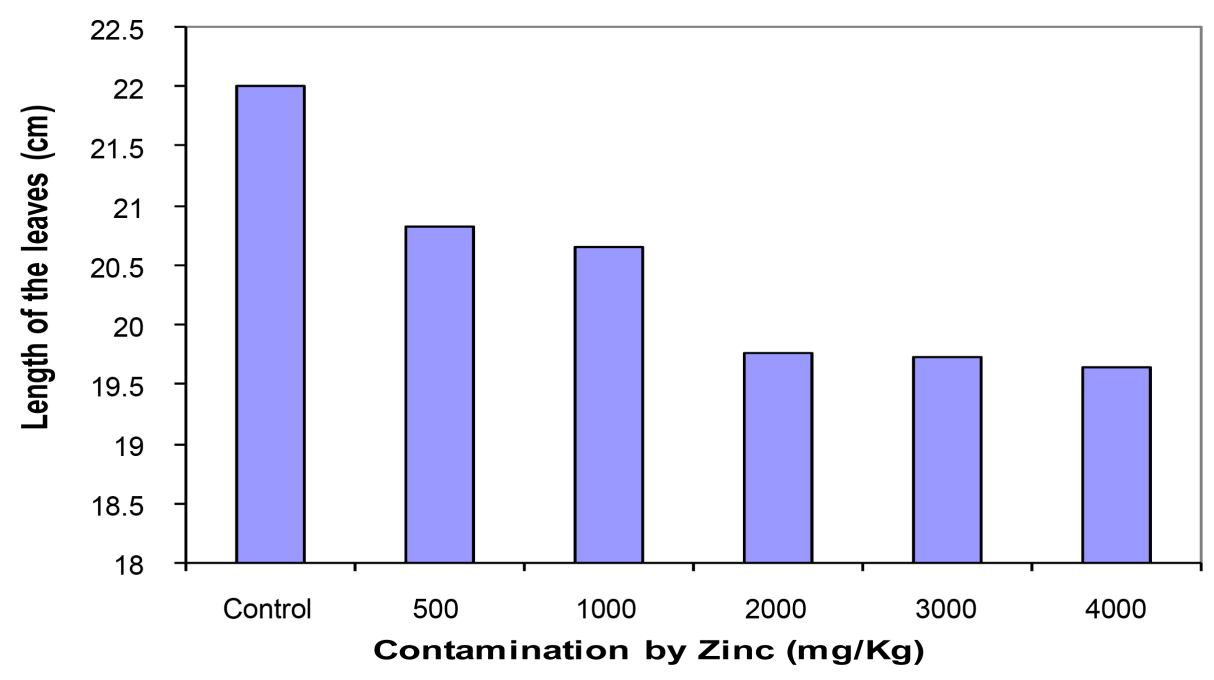

Figure 6. Evolution length of the leaves according to the concentration of zinc in the soil.

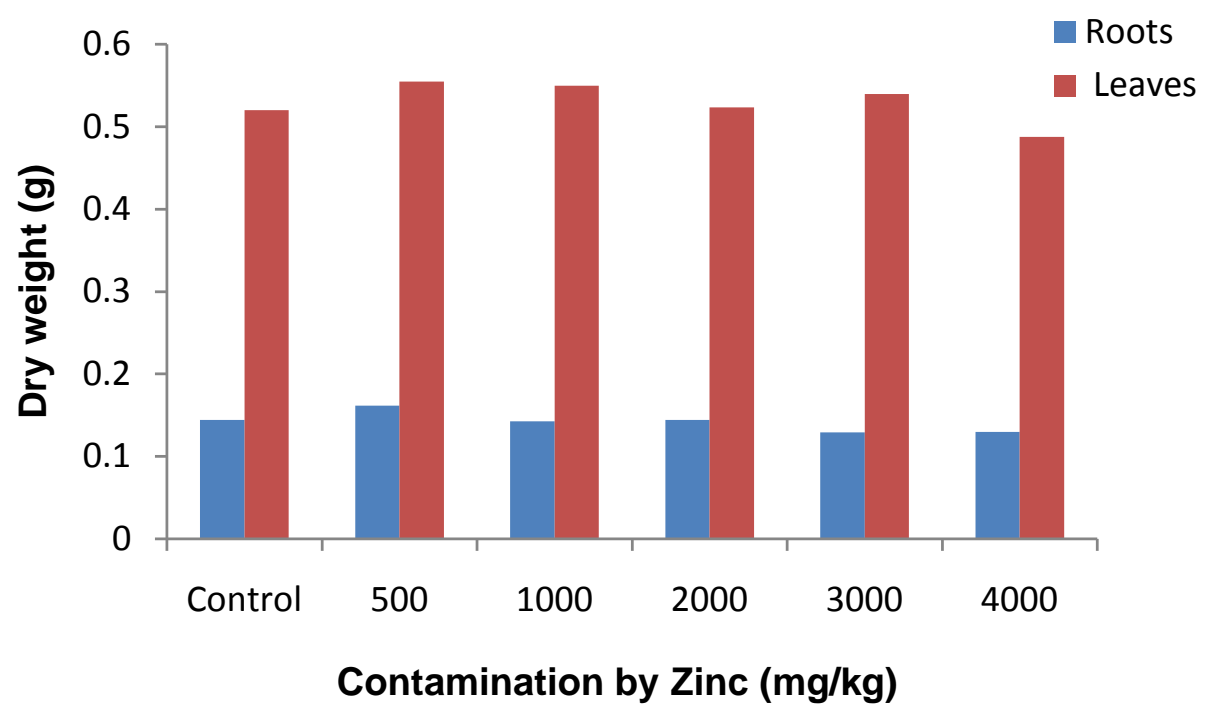

Figure 7. Dry weight of the roots and the leaves according to the contamination by zinc.

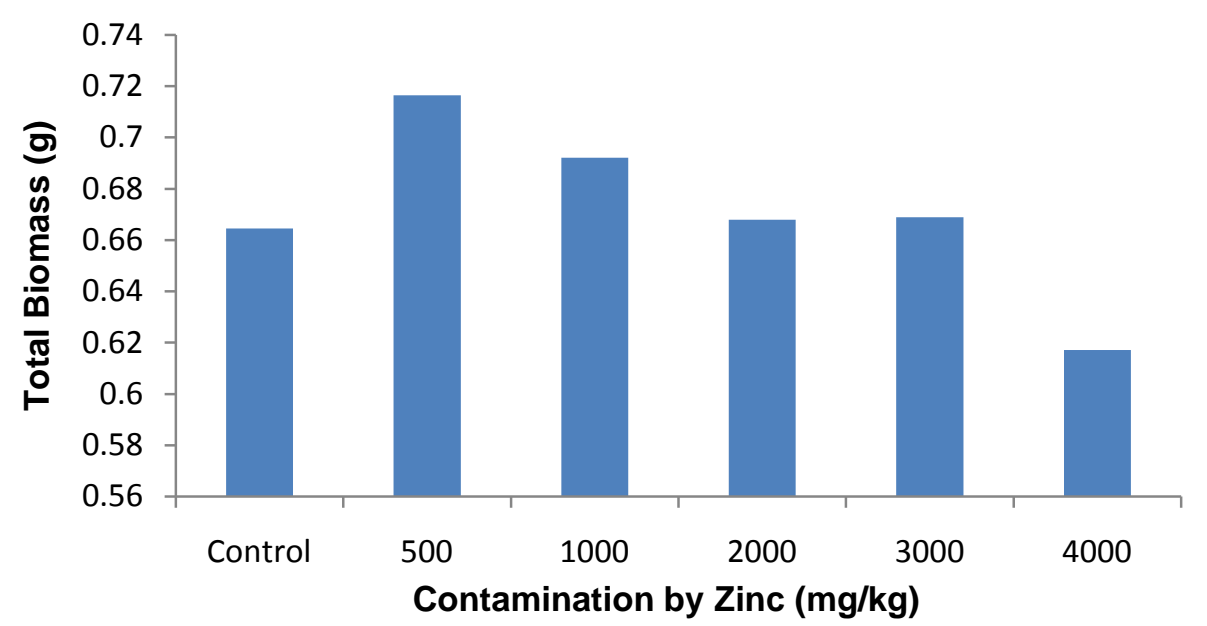

Figure 8. Evolution of the total biomass according to the contamination by zinc. 


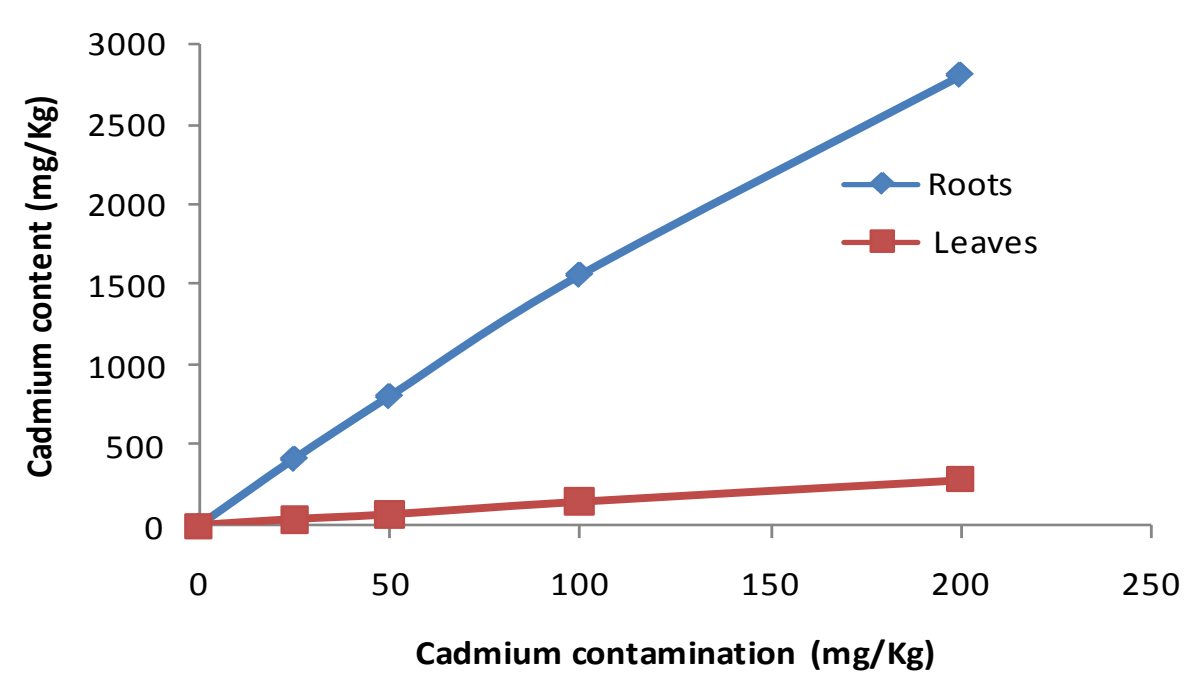

Figure 9. Evolution of the cadmium content in the roots and the leaves of the barley according to the contamination of cadmium.

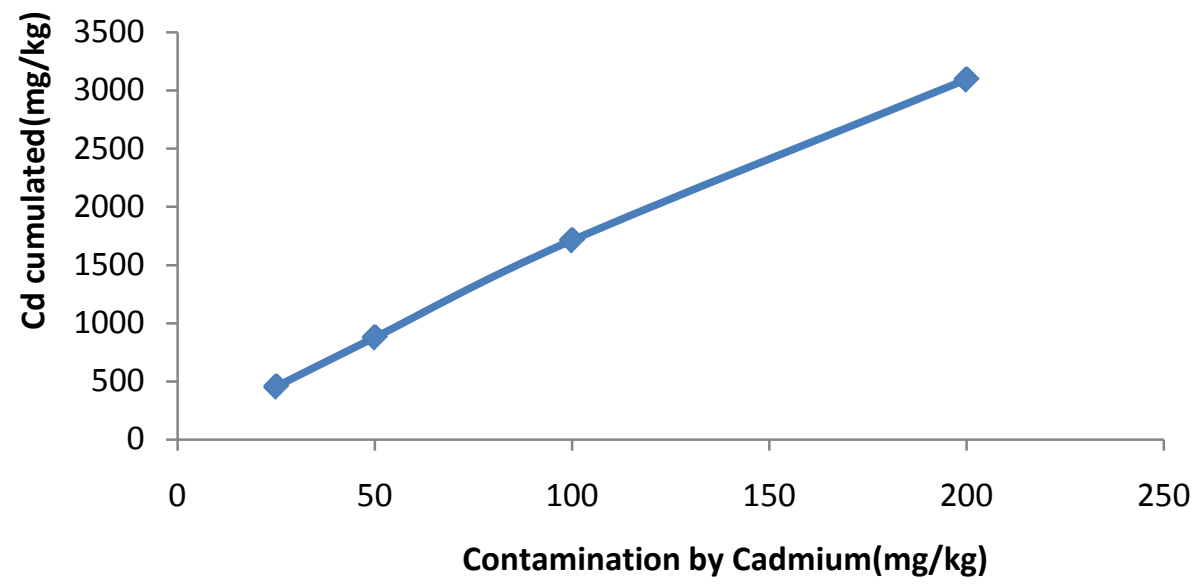

Figure 10. Evolution of the cadmium content cumulated in the barley according to the cadmium contamination.

contaminated soil, the results are also shown in Table 4.

\subsubsection{Content and Accumulation of Zinc in Barley}

After the digestion of the roots and leaves of the barley following the procedure mentioned above, we performed the analysis of zinc in roots and leaves of the harvested plant, the results are shown in Figure 11 we also represented the zinc cumulated by all the roots and leaves of the zinc by Figure 12.

These results allowed us to determine the bioaccumulation factor and factors translocution for each zinc content in the contaminated soil, the results are also shown in Table 5.

\section{Discussions}

The effect of heavy metals on plant growth, especially root growth has been reported by several authors [7]-[10].

Some studies were based on the determination of the biomass of the roots and leaves of biomass to evaluate the toxicity of the metal in plants. Some authors have reported that root growth is more sensitive than the leaves and thus are based on root length to study the toxicity addition to the effects on the production of root biomass and length, the roots may also respond to metal stress by changes in the pattern of root growth and morphology in the present study we investigated the impact of metals on the length of roots and leaves and the production of 
Table 4. Bioaccumulation factor and the tranlocution factor of barley (cadmium).

\begin{tabular}{ccccccc}
\hline \multirow{2}{*}{$\begin{array}{c}\text { Contamination by Cd } \\
(\mathrm{mg} / \mathrm{kg} \text { of soil) }\end{array}$} & \multicolumn{2}{c}{ Cd cumulated $(\mathrm{mg} / \mathrm{kg})$} & \multicolumn{3}{c}{ BF $(\%)$} & FT $\times 100$ \\
\cline { 2 - 5 } 0 (Control) & Roots $(\mathrm{cm})$ & Leaves $(\mathrm{cm})$ & Roots & Leaves & \\
25 & 0 & 0 & & & & 9.17 \\
50 & 416.8 & 38.2 & 16.672 & 0.15 & 8.44 \\
100 & 809.0 & 68.3 & 16.180 & 0.14 & 9.52 \\
200 & 1562.6 & 148.7 & 15.626 & 0.15 & 10.17 \\
\hline
\end{tabular}

Table 5. Bioaccumulation factor and the length and the tranlocution factor of barley (zinc).

\begin{tabular}{|c|c|c|c|c|c|}
\hline \multirow{2}{*}{$\begin{array}{l}\text { Contamination by } \mathrm{Zn} \\
\text { (mg/kg of soil) }\end{array}$} & \multicolumn{2}{|c|}{ Zn cumulated (mg/kg) } & \multicolumn{2}{|c|}{ BF (\%) } & \multirow{2}{*}{$\mathrm{FT} \times 100$} \\
\hline & Roots (cm) & Leaves (cm) & Roots & Leaves & \\
\hline 0 (Control) & $4900 \pm 210$ & $600 \pm 26$ & & & 12.25 \\
\hline 500 & $8450 \pm 730$ & $1200 \pm 61$ & 16.90 & 2.40 & 14.20 \\
\hline 1000 & $12450 \pm 410$ & $1450 \pm 73$ & 12.45 & 1.40 & 11.65 \\
\hline 2000 & $16400 \pm 850$ & $1550 \pm 88$ & 8.20 & 0.80 & 9.45 \\
\hline 3000 & $20700 \pm 631$ & $1650 \pm 110$ & 6.90 & 0.60 & 7.97 \\
\hline 4000 & $28700 \pm 990$ & $1900 \pm 97$ & 7.17 & 0.48 & 6.62 \\
\hline
\end{tabular}

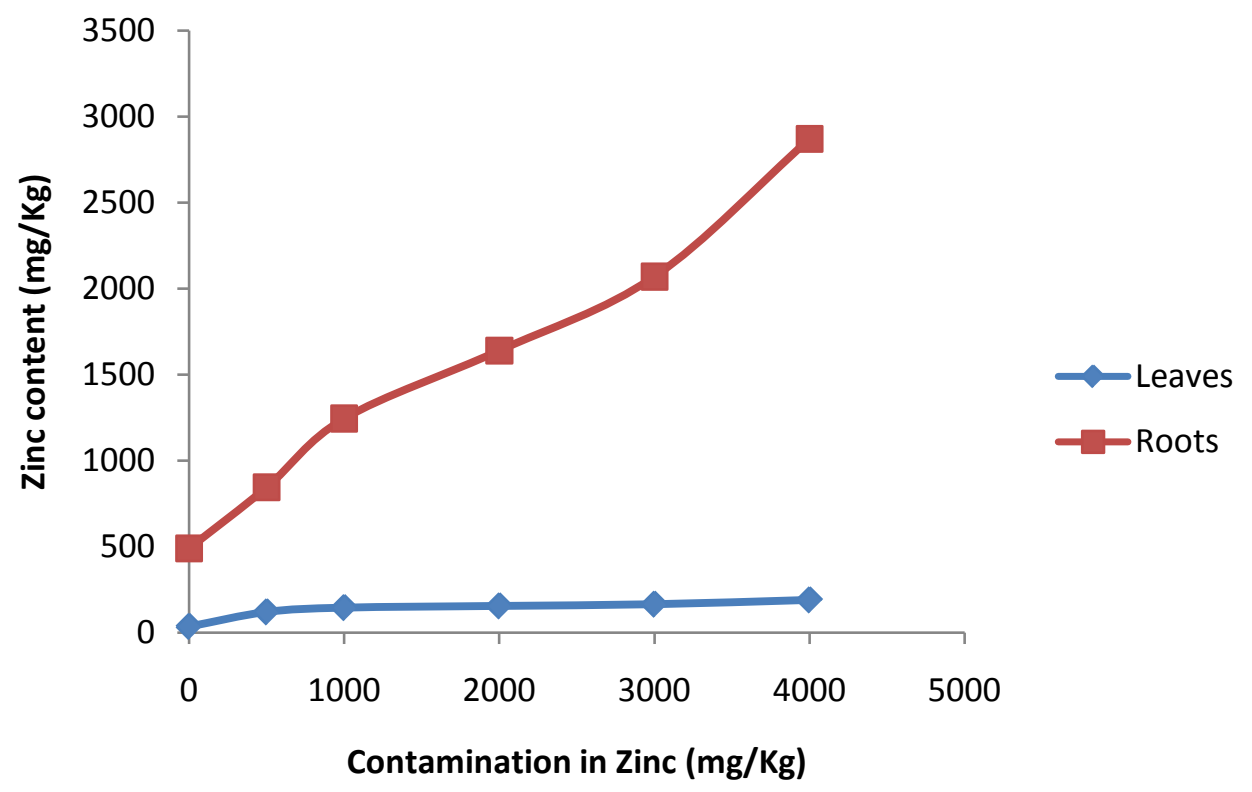

Figure 11. Evolution of the zinc content in the roots and the leaves of the barley according to the contamination of zinc.

root and aboveground biomass.

The lengths of the roots and leaves are shown in Figure 1 and Figure 2 for cadmium, and Figure 5 and Figure 6 in the zinc, metals reduce the lengths of the roots and leaves, but the most significant reduction in the presence of cadmium and respect the roots as reported by the literature, this reduction increases with the content of cadmium in the soil to reach $23.5 \%$ while it is around $9 \%$ for zinc. Similar reduction in root size was reported by [11]. A reduction in the size of the sheets was observed for the two metals of approximately $10 \%$ zinc and $13 \%$ cadmium. Signs of stress of the metal after 30 days of culture appear with more cadmium than zinc. This can be explained by the fact that cadmium is the most toxic heavy metal in the environment and that is to severe 


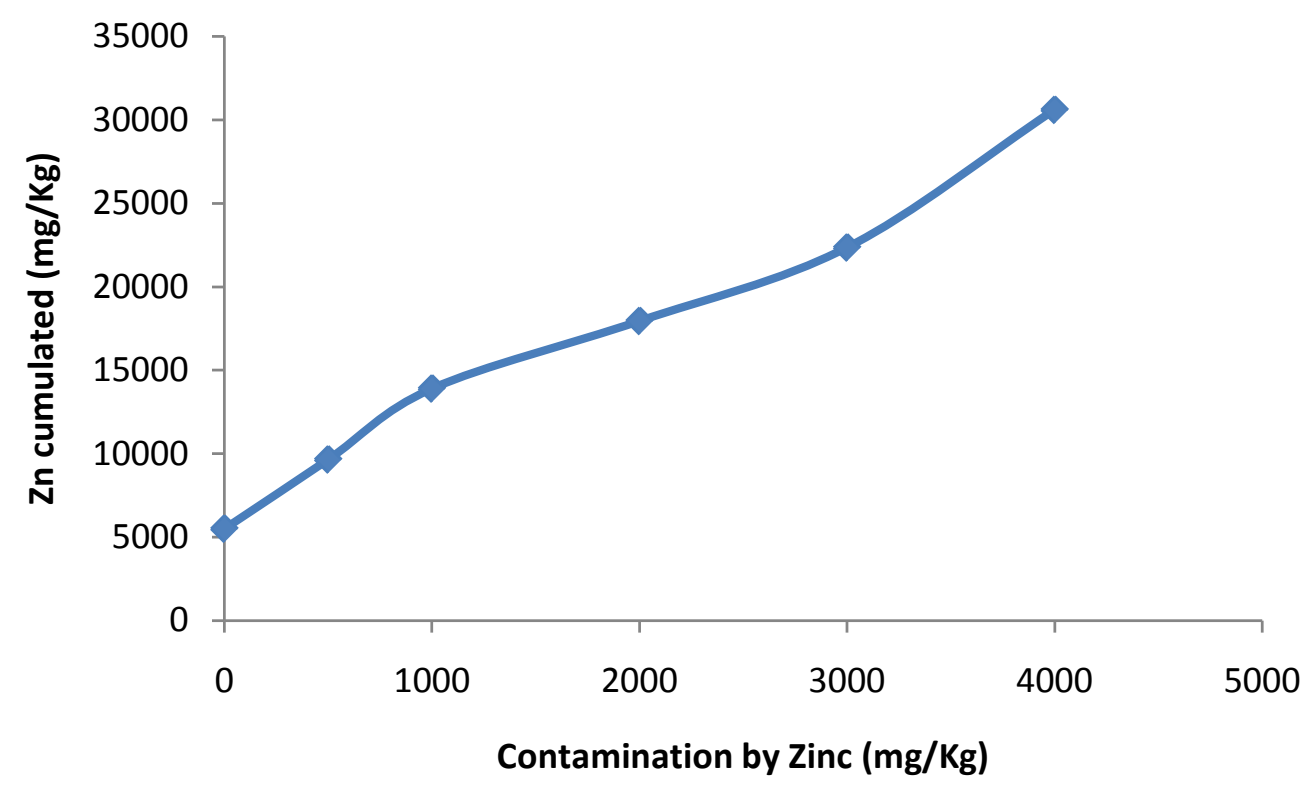

Figure 12. Evolution of the zinc content cumulated in the barley according to the zinc contamination.

toxicity to organisms [12] [13], against zinc is an essential trace element for plants, but can be highly toxic when present at a excessive concentration [14]. In our case we went up to $4000 \mathrm{mg} / \mathrm{kg}$ soil can be that extending the growing season for signs of stress are observed better.

The biomass of the roots and leaves and total biomass are shown in Figure 3 and Figure 4 for the cadmium, cadmium reduced total plant biomass as heavy metals generally reduce the solids content [15]. The reduction in biomass of leaves and roots, depending on the concentration of cadmium is not significant. The most significant reduction was observed for the barley grown in the contaminated at $500 \mathrm{mg} / \mathrm{kg}$ soil, but the reduction of leaf biomass was greater than the root contrary to what was expected. Concerning zinc, biomass and root and leaf total biomass are shown in Figure 7 and Figure 8, there is an increase of the total biomass of the plant by increasing the concentration of zinc in the soil, except for the concentration of $4000 \mathrm{mg} / \mathrm{kg}$ or there is a reduction. This time the effects of zinc are not apparent on the growth of barley after 30 days of culture, one might even believe that there is a better growth in the presence of zinc as biomass increases the metal is therefore tolerated by plants at this stage of culture.

Previous studies have shown that plants can suffer toxic effects if the soil reaches a high content of metals or $8 \mathrm{mg} / \mathrm{kg}$ for cadmium. The results of this study show that barley has no apparent signs of stress after thirty days of culture, it resisted even at a level of $200 \mathrm{mg} / \mathrm{kg}$ of soil. The parameter that has detected a stress due to the presence of cadmium is mainly the reduction of root size. We also note that barley is more tolerant to zinc, we observed no evidence of apparent even at $4000 \mathrm{mg} / \mathrm{kg}$ soil stress, and there was even increase the total biomass in the presence of strong zinc concentrations.

The accumulation of metals in the roots is larger than that of the leaves (Table 4 and Table 5). This is in agreement with the results of [16]-[18] which found that in general, the concentration of heavy metals accumulated in plant roots is higher than leaves, with one exception: the EDTA-assisted phytoextraction.

The bioconcentration factor (BF) has been widely used to estimate the potential of plants for phytoremediation [19] [20]. BF is an excellent indicator of the ability of metal accumulation by plants because it takes into account the metal content in the soil. A good accumulator plant should have a BF $>1000$. In our case, the maximum BCF roots we obtained are $166.72 \%$ to a content of $25 \mathrm{mg} / \mathrm{kg}$ for cadmium and $169 \%$ to a content of $500 \mathrm{mg} / \mathrm{kg}$ of zinc. The results also showed that, FC strongly decreases with the increase of the total metal content in soil (Table 4). This suggests that the capacity for phytoextraction decreases with increasing the concentration of $\mathrm{Zn}$ and $\mathrm{Cd}$ in the soil. This trend is more acute for $\mathrm{Zn}$ due to its higher concentration in the soil as compared to Cd.

These results are in agreement with those reported by other authors [19], which attribute this tendency to a self-adjusting mechanism of the plant, which limits the transport of heavy metals from the roots, the difficulties 
for metal uptake by plants suffered grown in contaminated soils. Audet and Charest [21] reported that the response to the decrease in BF values is probably related to increased metabolic cost associated with plant tolerance level of heavy metals, but they stressed that other factors influence the soil their interaction with plants, namely the toxicity of heavy metal poisoning causing plants, change in soil $\mathrm{pH}$, and mineral imbalances must be taken into account. TF can be used to estimate the ability of plants to translocate heavy metals from roots to shoots or their above-ground tissues that are easy to harvest [20] [22]. Metals concentrations in the leaves of barley were much lower than in the roots. Therefore, the translocation factor is too low so the metal remains in the roots it is not transferred to the harvestable parts that are most interesting for phytoextraction, which is typical for non-hyperaccumulor plants [23].

We cannot thus qualify our species of accumulator plant if it is cultivated in grounds contaminated by cadmium and zinc but its tolerance with these metals causes us to want to increase this accumulation for example using EDTA as chelating soil, knowing that addition of EDTA solution has a favorable effect on the absorption of metals, due to its properties acidification and chelation, it could be an effective amendment to improve the phytoextraction. However, this chelator is known to be persistent in soil due to its low biodegradability, which may pose a risk to the environment from leaching into groundwater. Therefore, studies should be conducted in order to find other natural and synthetic biodegradable chelating agents such as EDTA alternatives agents. And some studies have reported some bacteria able to increase the solubility and mobility of heavy metals [24]-[26].

\section{Conclusion}

It can be concluded from this study that a soil with a diverse flora can be contaminated with heavy metals and the species that grow on the ground floor, just being tolerant species to high concentrations of metals, where the interest should be brought to the soil pollution especially as it often is apparent point in our case. It will obviously not make a difference between the control pot and those contaminated with high concentrations of metals. These plants have a good yet growth contaminated with high levels of zinc and cadmium. We must ensure that contaminated sites are not cultured after decontamination to protect human health.

\section{References}

[1] Mejare, M. and Bulow, L. (2001) Metal-Binding Proteins and Peptides in Bioremediation and Phytoremediation of Heavy Metals. Trends in Biotechnology, 19, 67-73. http://dx.doi.org/10.1016/S0167-7799(00)01534-1

[2] Clemens, S., Palmgren, M.G. and Krämer, U. (2002) A Long Way Ahead: Understanding and Engineering Plant Metal Accumulation. Trends in Plant Science, 7, 309-314. http://dx.doi.org/10.1016/S1360-1385(02)02295-1

[3] Chaney, R.L., Malikz, M., Li, Y.M., Brown, S.L., Brewer, E.P., Angle, J.S. and Baker, A.J.M. (1997) Phytoremediation of Soil Metals. Current Opinion in Biotechnology, 8, 279-284. http://dx.doi.org/10.1016/S0958-1669(97)80004-3

[4] Bhargava, A., Carmona, F.F, Bhargava, M. and Srivastava, S. (2012) Approaches for Enhanced Phytoextraction of Heavy Metals. Journal of Environmental Management, 105,103-120. http://dx.doi.org/10.1016/j.jenvman.2012.04.002

[5] Sarret, G., Vangronsveld, J., Manceau, A., Musso, M., D’Haen, J., Menthonnex, J.J. and Hazemann, J.L. (2001) Accumulation forms of $\mathrm{Zn}$ and $\mathrm{Pb}$ in Phaseolus vulgaris in the Presence and Absence of EDTA. Environmental Science Technology, 35, 2854-2859. http://dx.doi.org/10.1021/es000219d

[6] Aubert, G. (1978) Relation entre le sol et cinq d'éricacées dans le sud est de la France. Oecol Plant, 13, 253-269.

[7] Baize, D. (1997) Teneurs en éléments traces métalliques dans les sols (France) INRA. Editions, Paris.

[8] Wisniewski, L. and Dickinson, N.M. (2003) Toxicity of Copper to Quercus robur (English Oak) Seedlings from a Copper-Rich Soil. Environmental and Experimental Botany, 50, 99-107. http://dx.doi.org/10.1016/S0098-8472(03)00005-4

[9] Xie, Y.H., An, S.Q., Yao, X., Xiao, K.Y. and Zhang, C. (2005) Short-Time Response in Root Morphology Vallisneria natans to Sediment Type and Water-Column Nutrient. Aquatic Botany, 81, 85-96. http://dx.doi.org/10.1016/j.aquabot.2004.12.001

[10] Fritioff, A. and Greger, M. (2006) Uptake and Distribution of $\mathrm{Zn}, \mathrm{Cu}, \mathrm{Cd}$, and $\mathrm{Pb}$ in an Aquatic Plant Potamogeton natans. Chemosphere, 63, 220-227. http://dx.doi.org/10.1016/j.chemosphere.2005.08.018

[11] Zheljazkov, V.D., Craker, L.E. and Xing, B.S. (2006) Effets de Cd, Pb, Cu et sur la croissance et le contenu de l'huile essentielle à l'aneth, menthe poivrée, basilic. Environmental and Experimental Botany, 58, 9-16. http://dx.doi.org/10.1016/j.envexpbot.2005.06.008

[12] Lopez, M.L., Peralta, J.R., Parsons, J.G., Gardea, J.L. and Duarte-Gardea, M. (2009) Effect of Indole-3-Acetic Acid, 
Kinetin, and Ethylenediaminetetraacetic Acid on Plant Growth and Uptake and Translocation of Lead, Micronutrients and Macronutrients in Alfalfa Plants. International Journal of Phytoremediation, 11, 131-149. http://dx.doi.org/10.1080/15226510802378434

[13] Das, P., Samantaray, S. and Rou, G.R. (1998) Studies on Cadmium Toxicity in Plants: A Review. Environmental Pollution, 98, 29-36. http://dx.doi.org/10.1016/S0269-7491(97)00110-3

[14] Singh, S., Eapen, S. and D’Souza, S.F. (2006) Cadmium Accumulation and Its Influence on Lipid Peroxidation and Antioxidative System in an Aquatic Plant, Bacopa monnieri L. Chemosphere, 62, 233-246. http://dx.doi.org/10.1016/j.chemosphere.2005.05.017

[15] Broadley, M.R., White, P.J., Hammond, J.P., Zelko, I. and Lux, A. (2007) Zinc in Plants. New Phytologist, 173, 677702. http://dx.doi.org/10.1111/j.1469-8137.2007.01996.x

[16] John, R., Ahmad, P., Gadgil, K. and Sharma, S. (2009) Heavy Metal Toxicity: Effect on Plant Growth, Biochemical Parameters and Metal Accumulation by Brassica juncea L. International Journal of Plant Production, 3, 65-76.

[17] Gheju, M. and Stelescu, I. (2013) Chelant-Assisted Phytoextraction and Accumulation of Zn by Zea mays. Journal of Environmental Management, 128, 631-636. http://dx.doi.org/10.1016/j.jenvman.2013.06.017

[18] Gheju, M., Balcu, I. and Ciopec, M. (2009) Analysis of Hexavalent Chromium Uptake by Plants in Polluted Soils. Ovidius University Annals of Chemistry, 20, 127-131.

[19] Mojiri, A. (2011) The Potential of Corn (Zea mays) for Phytoremediation of Soil Contaminated with Cadmium and Lead. Journal of Environmental Biology, 5, 17-22.

[20] Wang, X., Shan, X., Zhang, S. and Wen, B. (2004) A Model for the Evaluation of the Phytoavailability of Trace Elements to Vegetables under the Field Conditions. Chemosphere, 55, 811-822. http://dx.doi.org/10.1016/j.chemosphere.2003.12.003

[21] Yoon, J., Cao, X., Zhou, Q. and Ma, L.Q. (2006) Accumulation of Pb, Cu, and Zn in Native Plants Growing on a Contaminated Florida Site. Science of the Total Environment, 368, 456-464. http://dx.doi.org/10.1016/j.scitotenv.2006.01.016

[22] Audet, P. and Charest, C. (2007) Heavy Metal Phytoremediation from a Meta-Analytical Perspective. Environmental Pollution, 147, 231-237. http://dx.doi.org/10.1016/j.envpol.2006.08.011

[23] Nouri, J., Lorestani, B., Yousefi, N., Khorasani, N., Hasani, A.H., Seif, F. and Cheraghi, M. (2011) Phytoremediation Potential of Native Plants Grown in the Vicinity of Ahangaran Lead-Zinc Mine (Hamedan, Iran). Environmental Earth Sciences, 62, 639-644. http://dx.doi.org/10.1007/s12665-010-0553-z

[24] McGrath, S.P., Zhao, F.J. and Lombi, E. (2001) Plant and Rhizosphere Processes Involved in Phytoremediation of Metal-Contaminated Soils. Plant and Soil, 232, 207-214. http://dx.doi.org/10.1023/A:1010358708525

[25] Wu, S.C., Luo, Y.M., Cheung, K.C. and Wong, M.H. (2006) Influence of Bacteria on Pb and Zn Speciation, Mobility and Bioavailability in Soil: A Laboratory Study. Environmental Pollution, 144, 765-773. http://dx.doi.org/10.1016/j.envpol.2006.02.022

[26] Prapagdee, B., Chanprasert, M. and Mongkolsuk, M. (2013) Bioaugmentation with Cadmium-Resistant Plant GrowthPromoting Rhizobacteria to Assist Cadmium Phytoextraction by Helianthus annuus. Chemosphere, 92, 659-666.

http://dx.doi.org/10.1016/j.chemosphere.2013.01.082 
Scientific Research Publishing (SCIRP) is one of the largest Open Access journal publishers. It is currently publishing more than 200 open access, online, peer-reviewed journals covering a wide range of academic disciplines. SCIRP serves the worldwide academic communities and contributes to the progress and application of science with its publication.

Other selected journals from SCIRP are listed as below. Submit your manuscript to us via either submit@scirp.org or Online Submission Portal.
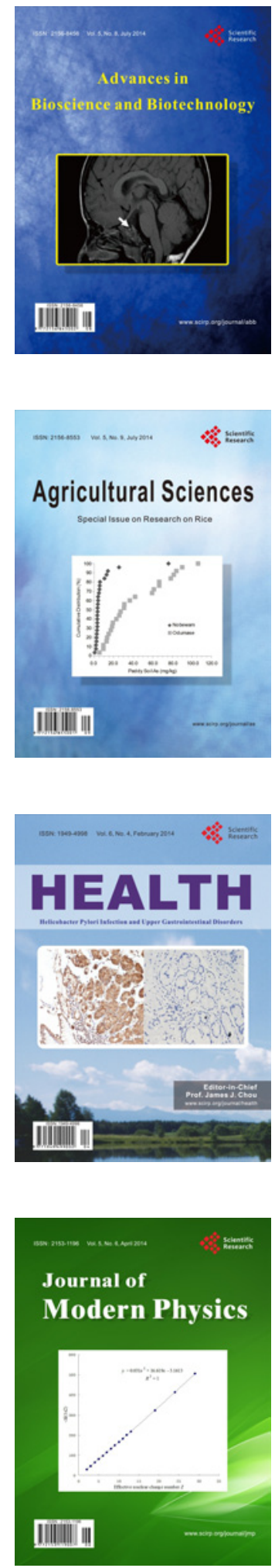
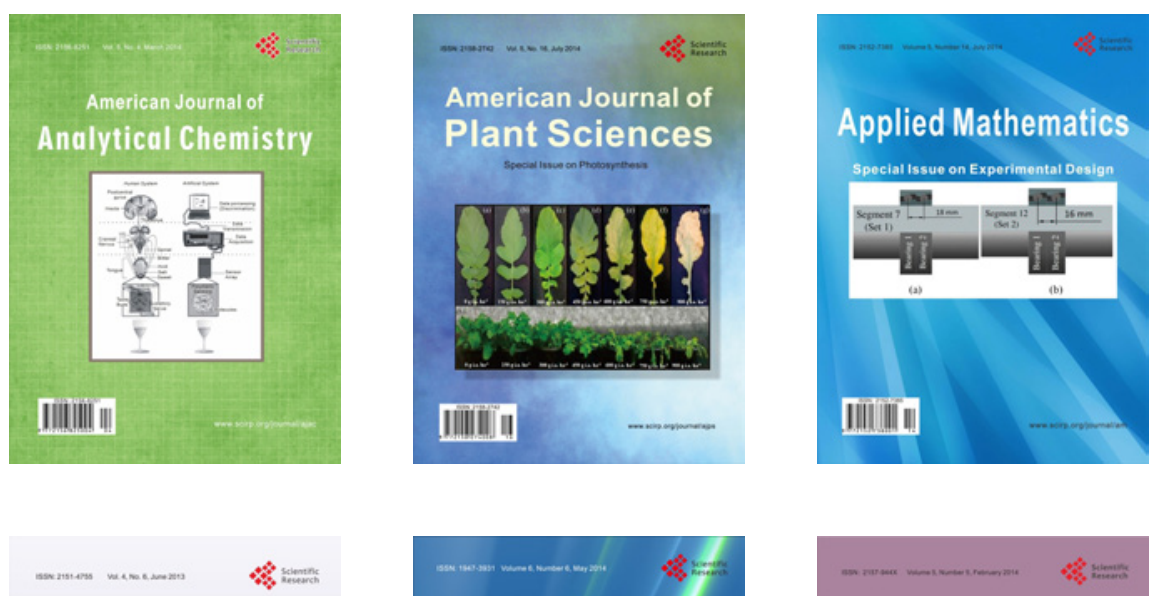

Creative Education
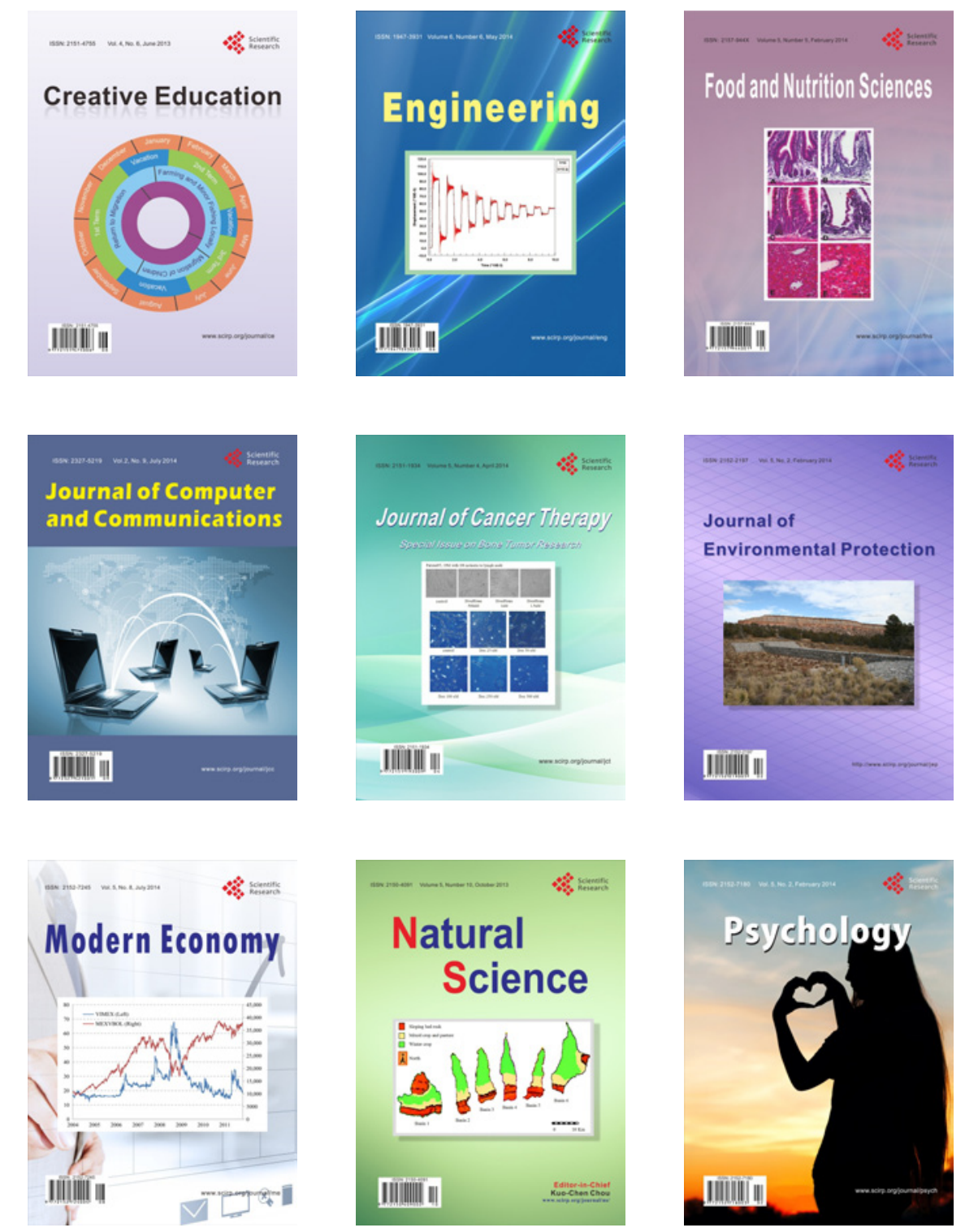